\title{
Poznámky k výskumu populárnej literatúry v stredoeurópskom kultúrnom kontexte
}

\section{Kristián Benyovszky}

\author{
BENYOVSZKY, K.: Notes on Research of Popular Literature in the \\ Central European Context \\ SLOVENSKÁ LITERATÚRA, vol. 69, 2022, no. 1, pp. 1-17 \\ DOI: https://doi.org/10.31577/slovlit.2022.69.1.1 \\ ORCID ID: https://orcid.org/0000-0002-0753-2718
}

\begin{abstract}
Key words: popular literature, popular culture, Central Europe, comparative literature studies
\end{abstract}

\begin{abstract}
The article maps current issues concerning popular literature in Central European cultures with a special emphasis on the Hungarian, Slovak, Czech and Polish contexts. It provides a partial overview of the current state of art and of the research approaches and outlines comparative perspectives. The research of popular literature and culture is done either from the inside, i.e. from the position of the experientially motivated recipient (recipient's perspective) or from the outside-from the position of an external observer. In the latter approach, the interest might lie in the wider external cultural and social contexts (sociocultural perspective) or in the summarisation of bibliographical data (archival perspective). These research lines testify to generically and thematically typical publications from all four linguistic areas-bibliographies, dictionaries, lexicons, case studies, deeper close readings and book-length research. The corpus this study takes as its material is composed of texts published in periodicals and online materials as platforms where popular literature is published and critically analysed. It also takes into consideration Central European feedback on the writers of the Western canon, imagological analysis of national stereotypes, popular socialist culture, fandom and fan literature and intermediality and transmediality of popular culture.
\end{abstract}

Klúčové slová: populárna literatúra, populárna kultúra, stredná Európa, komparatistika 

ýznam dvoch klúčových slov štúdie nie je ani zd'aleka samozrejmý, existuje nespočetné množstvo rôznych, vzájomne sa doplňujúcich, ale i nekompatibilných a divergentných definícií populárnej literatúry, respektíve kultúry a rovnako aj strednej Európy. Tento rozptyl je tým širší, čím viac disciplín je na tom zainteresovaných. ${ }^{1}$

Populárna kultúra je vel'mi komplexný jav, ktorý má niekol'ko rovín a podôb, so záberom od konkrétnych diel, žánrov a médií až k predmetom a rituálom každodenného života. Populárnu kultúru - a v rámci toho aj literatúru - chápem ako autonómny subsystém kultúry, ktorá ,,sama vo svojom rámci disponuje vysokým a nízkym, a predovšetkým disponuje vlastným znakovým systémom, vlastným jazykom, sčasti korešpondujúcim, ale v samom fundamente nezlučitel'ným s jazykmi tradičných umeleckých druhov" (Malíček 2008: 22). Takto chápaná populárna kultúra a literatúra ako jej súčast' vyniká širokou dostupnostou a zameranostou na recipienta, žáner, hrdinov a zisk. Široká dostupnost' pochádza z masovej medializovanosti diel (distribuujú sa cez rozmanité druhy nosičov), relatívne nízkej ceny a recepčnej prístupnosti obsahu.

Stredoeurópsky kontext vnímam ako vzt'ah literatúr, kultúr a vedeckých komunít krajín Vyšehradskej štvorky. Tieto krajiny spája nielen geografická blízkost', ale v značnej miere aj spoločná história, podobný sociálny a ekonomický vývin (najmä v 20. storočí) a spoločné umelecko-kultúrne tradície. To všetko sa odráža aj v metodológii a klúčových oblastiach výskumu populárnej kultúry v danom areáli.

Pre výskum populárnej literatúry a kultúry má každá národná veda vlastné historické rámce i aktuálne určujúce paradigmy s preferenciami postojov, metód a tém. Týmto súvislostiam (najmä v komparatívnej perspektíve) sa doposial' venovalo málo pozornosti. Jednu z mála výnimiek predstavuje štúdia slovenskej autorky Stanislavy Sivčovej, ktorá porovnáva minulost'a súčasné trendy výskumu populárnej literatúry v slovenskej a pol'skej literárnej vede a humanistike (Sivčová 2017). Treba spomenút i prehl'adnú rekapituláciu českého editora a publicistu Antonína K. K. Kudláča o najdôležitejších etapách a výsledkoch v tomto smere v českom prostredí po roku 1989 (Kudláč 2014). V Mad'arsku neboli zatial' ešte publikované podobne zamerané prehl'adové štúdie o dianí a paradigmatických zmenách vo vedách o kultúre, čiastkové výsledky boli zhrnuté v súvislosti s doterajšou odbornou reflexiou niektorých populárnych žánrov (Hegedűs 2012) alebo sa týkali skôr teoretických otázok vysokej a populárnej, respektíve masovej kultúry (Sántha 1996, Bárány 2001).

Bolo by potrebných viacero obdobných sondáží a prierezových článkov, aby sme sa postupne mohli dopracovat' $\mathrm{k}$ diferencovanejšiemu obrazu stredoeurópskeho kontextu výskumov populárnej kultúry. Tieto výskumy sa totiž obyčajne vedú oddelene, bez vedomia ostatných troch strán, málokedy možno hovorit' o kooperácii v tejto oblasti. Vzájomná informovanost' je pravdepodobne najlepšia v česko-slovenských reláciách, naopak, v humanitných vedách v Mad'arsku sa vie ovela menej o výsledkoch aktivít „slovanských kolegov“ alebo zostávajú celkom stranou. Je to spôsobené jednak jazykovými bariérami (angličtina sa v tomto kontexte ešte natol'ko neetablovala, že by sme mohli hovorit' o nejakom spoločnom

1 Prehl'ad o jednotlivých koncepciách vysokej a nízkej, populárnej a masovej kultúry podáva Plencner 2013. Koncepcie strednej Európy syntetizujúcim spôsobom porovnáva Miloš Zelenka (Zelenka 2008: 3-58). 
korpuse tematicky a koncepčne vyprofilovaných odborných textov), jednak dominantným vplyvom západných, prevažne angloamerických cultural studies či nemeckej Medienwissenschaft. Tie totiž ponúkajú nielen teoreticko-metodologický rámec individuálnych a kolektívnych výskumov, ale zároveň do vel'kej miery určujú aj okruh preferovaných autorov a diel, v dôsledku čoho sa česká, slovenská a pol'ská popkultúrna produkcia a ich odborná reflexia dostávajú do úzadia.

Jedným z ciel'ov štúdie je poukázat'na inšpiratívne výstupy každej zo štyroch vybraných stredoeurópskych národných filológií, na ich latentnú prepojenost' a styčné body medzi nimi, a zároveň navrhnút d'alšie možné cesty komparatívnych skúmaní takto regionálne vymedzenej stredoeurópskej populárnej literatúry. Inými slovami: budem referovat' nielen o doterajších vedeckých publikáciách, ale rovnako beriem do úvahy aj to, čo nás čaká v budúcnosti, teda čo by bolo potrebné, žiaduce v danej oblasti vykonat'. Moje poznámky sa preto budú týkat' celého radu fenoménov ako zážitková a faktografická motivácia vedeckej práce, reprezentácia spoločných historických skúseností regiónu, vplyv politickej ideológie na tvorbu, dynamika populárnych žánrov, interakcia rôznych médií, fanúšikovská kultúra, funkcia umeleckého prekladu a kritickej recepcie diel.

Z povahy skúmaných javov, predovšetkým z druhovej a tematicko-žánrovej rozmanitosti populárnej literatúry vyplýva, že ponúkaný prehlad nemôže byt' iný než iba fragmentárny, výberový, že bude ponúkat' iba isté prierezy, upriamovat pozornost' len na niektoré markantné tendencie a v závere anticipovat'iba zopár línií budúcich výskumov. V centre záujmu stojí literatúra, no s presahmi k iným médiám mimoriadne rozpriestraneného a vnútorne členitého pol'a populárnej kultúry. Takýto kontextuálno-senzibilný prístup odôvodňuje samotný spôsob bytia literárnych diel v tomto prostredí tvorby a recepcie, ktoré je navyše čoraz väčšmi intermediálne a transmediálne poznačené.

\section{Populárna kultúra zvnútra: účastnícka perspektíva}

S istým zjednodušením možno povedat', že z hl'adiska dominantného postoja seriózny vedecký výskum populárnej literatúry a kultúry sa uskutočňuje bud' zvnútra, z pozície zážitkovo motivovaného recipienta, alebo zvonka, z pozície externého pozorovatel'a s primárnym záujmom o širšie vonkajšie kontexty spoločnosti a kultúry či o sumarizáciu bibliografických údajov tvorby. V prvom prípade hovoríme o uplatnení účastníckej perspektívy, v druhom prípade o sociokultúrnej a archivujúcej perspektíve.

Uplatnenie účastníckej perspektívy sa prejavuje v osobnej angažovanosti autora - odborníka, ktorý nezastiera, že sám je vášnivým čitatel'om a fanúšikom daného žánru či autora. Analyzované diela vníma ako hodné vedeckého záujmu pre ich estetické kvality. Prístup a metodika interpretačnej práce sa ničím nelíšia od zvyklostí profesionálneho „narábania“ s dielami vysokej, kanonizovanej literatúry. Skúmajú sa dobovo, žánrovo či autorsky signifikantné tvárne postupy, kompozícia, štýl, motivická štruktúra textu, významové vrstvy, intertextuálne väzby a podobne. Deklarovaný postoj „konzumenta“ ovplyvňuje aj štýl a žánrový rámec výkladu. $Z$ osobnej zážitkovej angažovanosti pramení väčšia miera sebavýrazu autora odborného textu: subjektívnost', emocionálna zainteresovanost', hodnotenie a niekedy aj mierna hovorová expresívnost' výrazu. Tieto texty preto často inklinujú, aspoň v niektorých partiách, k esejistickým formuláciám. 

dec Tomáš Horváth, ktorý je bezpochyby najerudovanejším znalcom detektívky na Slovensku. Výsledky dlhoročného výskumu žánru kompletizoval v roku 2011 v impozantnej genologicko-interpretačnej monografii Tajomstvo a vražda. Svoje osobné pohnútky a odborne fundovaný hedonistický postoj sformuloval hned' na začiatku knihy: „,pisatel' tejto práce nijako nezastiera, že je sám vášnivým čitatel'om a fanúšikom detektívok a že skúmaný žáner nie je preňho len demonštratívnym literárnym materiálom, na ktorom sa dajú vhodne odhal'ovat štruktúry (pre ich schematickost') a vhodne modelovat'žáner, ,príkladný ' pre genologickú konštrukciu“ (Horváth 2011:9). T. Horváth skúma žáner predovšetkým z textovo-imanentného hl'adiska, zaujímajú ho textové mechanizmy (konštrukčný grif) diel, pomocou ktorých autor „dokáže modelovému čitatel'ovi zastriet' riešenie záhady a prekvapit' ho ním, hoci čitatel' má všetky fakty potrebné na vyriešenie záhady k dispozícii“ (Horváth 2011: 9). Podl'a neho sú to tie stratégie, „pre ktoré čítame detektívky, takpovediac, v prvom rade [...], pre rozkošz čítania, jeho erotiku, spočívajúcu v nastolení (zdanlivo neriešitel'nej) záhady“ (Horváth 2011: 8) a jej konečného rozuzlenia.

Český autor A. K. K. Kudláč na margo obsahu a koncepcie svojej knihy Literatura přes palubu poznamenáva, že jednotlivé texty vytvárajú akúsi mapu jeho odborného, najmä však čitatel'ského vývinu, pretože „za čtenáře se považuji především“ (Kudláč 2010: 10). Otvorene priznáva sympatie k istým populárnym žánrom (detektívka, fantasy, horor, historický román), čo však u neho nevylučuje, ba priam predpokladá istý stupeň náročnosti voči jazykovo-literárnej úrovni textov: „A protože mám kriminální žánr opravdu hodně rád, každé jeho mrzačení nezvládnutým a nesvědomitým řemeslem ve mně budí vztek“" (Kudláč 2010: 52). Dôkazom toho, že pozície priameho účastníka a pozorovatel'a sa a priori nevylučujú, je autorova nasledujúca monografia Anatomie pocitu úžasu, v ktorej sa zaoberá kultúrnym a sociálnym pozadím českej populárnej fantastiky v rokoch 1990 - 2012. Robí to však deklaratívne ako fanúšik žánru a neorganizovaný člen tolkienistického fandomu (Kudláč 2016: 158).

Juraj Malíček, slovenský teoretik a pravidelný glosátor a recenzent popkultúrnych diel, sa v knihe Vademecum popkultúry podiel'al na vytvorení pragmatickej alternatívy existujúcich estetických teórií. V duchu Nitrianskej školy vychádza z recepčného bytia popkultúrneho artefaktu, čo znamená, že za určujúci aspekt jeho výkladu pokladá kategóriu zážitkovosti. Jeho vol'ba účastníckej perspektívy nie je daná iba metodologickým usmernením „školiaceho pracoviska“, ale vychádza z intencie tvorby a spôsobu percepcie tohto druhu diel: „Popkultúrna poetika vychádza z osobného zakúsenia kvality a jej najspol'ahlivejším a najzodpovednejším ukazovatel'om je personálny vkus, pretavený do interpretačnej zručnosti, ktorej prostredníctvom popkultúrne artefakty číame“ (Malíček 2008:36). Takýto prístup si vyžaduje aj zmenu štýlu odbornej reflexie a vytvorenie nového slovníka, „ktorý by umožňoval premýšlat' o estetických aspektoch popkultúry bez apriórneho hendikepu, ktorým popkultúru zatažujú dosial' existujúce slovníky“ (Malíček 2008: 11).

Priame a nepriame prejavy rovnakej atitúdy môžeme nájst' tiež v prácach mad'arských odborníkov, akými sú napríklad Tamás Bényei (2009), Péter H. Nagy (2016), József Keserü (2021) či Tibor Bárány (2001). 
V prípade archivujúcej perspektívy ide predovšetkým o systematické zachytenie výsledkov tvorby populárnej literatúry vo forme bibliografických zoznamov a katalógov, slovníkov či lexikónov. Vzniknuté súpisy, registre a hesláre obsahujú základné životopisné údaje o autoroch, knižných parametroch ich diel, ilustrátoroch, vydavatel'stvách, edíciách, prípadne aj distribútoroch. Z charakteru žánru vyplýva, že na stránkach týchto publikácií sa neriešia delikátne otázky estetickej diferencie medzi takzvanou vysokou, elitnou a nízkou, populárnou literárnou tvorbou, hodnotový aspekt sa môže, ale nemusí prejavit' iba v úvodných kapitolách alebo dodatočných komentároch redaktorov, respektíve v niektorých z citovaných dobových kritických ohlasov. Namiesto pojmovo-zážitkovej štylizácie tu dominuje faktografickost', opisnost', rezervovanost' a formálnost' výrazu. Netreba zvlášt' zdôrazňovat, že publikácie tohto typu sú predpokladom a nevyhnutným dôkazovým materiálom akejkolvek serióznej, empiricky podloženej literárnohistorickej práce.

Čo sa týka slovníkov, treba povedat', že na dielo, ktoré by sa formátom, rozsahom záberu a kompletnostou spracovania vyrovnalo pol'skému redakčnému výstupu Tadeusza Żabského (Żabski 2006), je ešte potrebné čakat', hoci na českej, mad'arskej a slovenskej scéne sú $\mathrm{k}$ dispozícii slovníky a lexikóny iného typu. Už spomenuté Vademecum popkultúry J. Malíčka obsahuje dva tezaury: prvý mapuje príznakové vlastnosti popkultúry, druhý podáva výklad pojmov jej „,newspeaku“ (Malíček 2008: 51-84, 85-120). V tejto súvislosti možno odkázat' aj na Stownik nowych gatunków i zjawisk, ktorý popri tradičných žánrových kategóriách obsahuje aj heslá ako fanfikcia, internetový komiks, poézia SMS či slam poetry (Potrykus-Wożniak 2011).

Ďalším typom archivujúceho knižného spracovania diel populárnej literatúry sú autorské lexikóny. Prinášajú životopisné, literárnohistorické a poetické údaje o tvorbe niektorého významného predstavitela daného žánru. Tu možno odkázat' na dve inšpiratívne mad'arské publikácie. Prvá nesie názov Agatha Christie krimikalauz (Agatha Christie krimi-sprievodca) a jej autori Róbert Hadnagy a Gabriella Molnár sú spolahlivými a erudovanými sprievodcami vo svete diel král'ovnej detektívky. Jednotlivé heslá stredného i väčšieho rozsahu obsahujú okrem základných bibliografických údajov románov, poviedok, rozhlasových a divadelných hier Agathy Christie a ich filmových adaptácií-v rozsahu názov, dátum vydania, premiéra, mad'arský preklad, prípadne preklady diela, režisér, scenárista a herecké obsadenie - aj krátke resumé, zoznam a charakteristiku postáv, informácie o ich migrácii v autorskom medzitextovom priestore a tiež upozornenia na rôzne kuriozity, doplňujúce a zákulisné informácie, ako sú životopisné referencie a kritický ohlas diel, vyjadrenia autorky a podobne (Hadnagy - Molnár 2004).

Druhý inšpiratívny mad'arský titul je spojený s menom najpopulárnejšieho autora mad'arskej zábavnej literatúry medzivojnového obdobia-Jenő Rejtő (1905-1943) sa preslávil hlavne humoristicky ladenými legionárskymi románmi, westernami a detektívnymi paródiami, okrem toho bol aj úspešným tvorcom kabaretných hier. Jeho romány vynikajú originálnou jazykovou komikou, grotesknými situáciami a niekedy až absurdnými zvratmi, mnohé výroky protagonistov sa stali súčast'ou mad'arskej frazeológie. (Niektoré jeho romány boli preložené aj do slovenčiny a češtiny.) Oblúbenost' medzi čitatel'mi si Rejtő zachoval dodnes, o čom svedčia nové a nové vydania jeho diel a takisto samostatná kapitola o ňom 
v najnovších akademických dejinách mad'arskej literatúry. Ďalším znakom zvyšujúceho sa odborného záujmu o tvorbu tohto autora je autorský lexikón Rejtölexikon (Rejtö lexikón) s podnázvom „Svet 27 románov Jenő Rejtőa v 2500 heslách“ (Farkas 2012). Kniha pozostáva zo štyroch častí. Prvá, najobsiahlejšia čast' prináša bohatý register románových postáv autora so základnými informáciami o ich pôvode, vonkajších a vnútorných vlastnostiach a pohybe v Rejtőovom fikčnom univerze. Druhá čast' obsahuje zoznam najdôležitejších „dejotvorných“ objektov, predovšetkým dopravných prostriedkov (autá, lode, lietadlá), artefaktov, zbraní a rôznych úžitkových predmetov protagonistov. $\mathrm{V}$ tretej časti sú vysvetlené niektoré klúčové pojmy románov a posledná čast' je anotovaným zoznamom miest (krajiny, mestá, ulice, krčmy a rôzne inštitúcie).

Z bibliografických prác treba na prvom mieste spomenút český titul Svět rodokapsů, ktorý obsahuje komentovaný súpis českých zošitových románových edícií (Romány do kapsy) z tridsiatych a zo štyridsiatych rokov 20. storočia. Záchranná práca Pavla Janáčka a Michala Jareša svojou dôkladnostou, systematickost'ou a prehl'adnou usporiadanostou údajov môže poslúžit' ako vzor aj pre bádatel'ov ostatných stredoeurópskych literatúr (Janáček - Jareš 2003).

V mad'arskej literárnej vede publikáciu podobného zamerania (no rozsahovo a informačne skromnejšiu) predstavuje ilustrovaná bibliografia pôvodnej a prekladovej populárnej literatúry medzivojnového obdobia od Lászlóa Gróba, ktorá má zatial' pät' zväzkov. Redaktor v úvode prvého diela priznáva, že jeho hlavným ciel'om nebolo estetické hodnotenie publikácií, ale snaha predíst' tomu, aby literatúra tohto typu zapadla do absolútneho zabudnutia (Grób 2012: 5).

Ak porovnáme dve spomenuté publikácie, môžeme si všimnút vel'mi podobné procesy adaptácie zahraničných literárnych vzorov, knižného marketingu a s tým súvisiacich autorských a prekladatel'ských stratégií. V autorskom registri českých edícií románov do vrecka (rodokaps) dokonca figurujú aj mad'arskí spisovatelia (Sándor Bródy, Béla Illés, Jenő Kalmán, László Tabi). Bolo by zaujímavé zistit', nakol'ko korešponduje ich zahraničná pozícia populárneho autora s domácou literárnohistorickou kategorizáciou a kánonom. Ďalším styčným bodom je archivácia mien ilustrátorov populárnych románov (L. Grób prináša aj kvalitné reprodukcie obálok), ktorí sa tiež podiel'ali na formovaní verejného obrazu jednotlivých autorov, žánrov a edícií. V obidvoch literatúrach, vrátane prekladovej tvorby, vidiet' silný vplyv súdobého filmu, čo sa prejavuje v adaptácii, respektíve remedializácii žánrovo typických filmových scén a hrdinov na obálkach zošitových vydaní. Otvára sa tu možnost' porovnávania výrazových tendencií ilustrovania tejto literárnej produkcie a rôznych foriem jej vizuálnej paratextualizácie v stredoeurópskych literatúrach.

Podobné bibliografie by bolo potrebné zostavovat pravidelne - nielen o populárnej beletrii, ale aj o jej odbornej reflexii. Tak ako to robí pol'ský časopis Literatura i kultura popularna, vydávaný Vroclavskou univerzitou, najvýznamnejšie a vlastne jediné odborné periodikum v strednej Európe, ktoré sa už vyše dvadsat rokov venuje výhradne populárnej kultúre, domácej i zahraničnej. Na stránkach tohto časopisu sa s určitou pravidelnostou objavujú aj bibliografie pol'ských monografií, zborníkov a časopiseckých článkov so vztahom k danej téme za vybrané obdobie. 
Archiváciu literárnych výstupov populárnej literatúry treba rozšírit' aj na iné nosiče, než sú knihy a zošitové edície. Je známe, že najdôležitejšou publikačnou platformou populárnej literatúry približne od polovice 19. storočia sa v USA a západnej Európe stala periodická tlač: masovo distribuované, lacné, a preto každému dostupné denníky a týždenníky senzačného charakteru, ktoré popri tematicky vel'mi rôznorodých článkoch, inzercii a reklamách uverejňovali aj poviedky, novely a romány na pokračovanie. Predpokladom čitatel'sky aj komerčne úspešného fungovania tohto typu tlače bola rozvinutá vel'komestská kultúra. Český vedec Jakub Machek sleduje tieto procesy v stredoeurópskom priestore, predovšetkým v domácom českom prostredí, pričom poukazuje na tie spoločenské, politické, ekonomické a inštitucionálne zmeny, ktoré postupne viedli k vzniku vel'komestskej kultúry a vydávaniu tlačených médií vel'mi podobného profilu podl'a berlínskych a viedenských vzorov tak v Prahe, ako i v Krakove (Machek 2017), a ja dodávam, že tiež v Budapešti. Núka sa tu teda cesta osobitej analýzy a následne porovnávania týchto periodík, ich štruktúry, žánrových a tematických preferencií populárnej literatúry, ktorá bola v týchto periodikách publikovaná, ako aj kánonu najvýznamnejších autorov a diel. Obzvlášt' zaujímavé môžu byt' rôzne dobovo podmienené prechodné formy prekladu, parafrázy, tendenčné prepisy a plagizovanie. Napríklad v súvislosti s románom na pokračovanie v 19. storočí (pôvodne označovanom ako román feuilleton), ktorý mad'arská literárna vedkyňa Ágnes Hansági označila za par excellence komparatistický žáner, s poukazom na to, že paralelná cirkulácia tých istých diel v rôznych krajinách v rôznych prekladoch a prepisoch, často bez udania bibliografických údajov originálu alebo so zamlčaním mena prekladatel'a, relativizovala hierarchiu a zásadný rozdiel medzi originálom a prekladom. Napomohlo tomu aj dominantné domáce jazykové prostredie okolo jednotlivých románových pokračovaní (Hansági 2017: 82-84). Vel'mi podobná publikačná prax týchto diel v stredoeurópskych periodikách môže byt' podkladom pre komparácie, ktoré budú prepájat tradičný literárno-genologický, translatologický a mediálne orientovaný výskum.

Obdobné výskumy by bolo osožné podniknút aj v prípade periodík neskorších období, a to vrátane tvorby v žánrovo špecifických literárnych časopisoch, pulpových magazínoch či vo fanzinoch. Bolo by napríklad nanajvýš aktuálne spracovat' vo forme anotovanej bibliografie so sprievodnou štúdiou preklady západných a stredoeurópskych detektívnych poviedok a románov, ktoré boli uverejnené v mad'arskom literárnom týždenníku Rakéta regényújság (1974-1994). Niektoré tituly dodnes nevyšli knižne a sú dostupné iba v tomto periodiku.

\section{Preklad, recepcia, literárny ohlas}

Vd'aka už existujúcim bibliografiám (a výhl'adovo aj vd'aka potenciálnym) sa otvára d'alší dôležitý horizont komparatívneho výskumu stredoeurópskych populárnych literatúr - recepcia a kritická analýza prekladov. Načrtnem niekol'ko možných výskumných aspektov:

1. Kvantitatívne a kvalitatívne ukazovatele prekladu vybraných autorov, diel alebo žánrov v literatúrach krajín Vyšehradskej štvorky. Východiskové otázky v prípade detektívky by mohli byt' nasledujúce: Ktorí boli najprekladanejší českí, pol'skí a slovenskí autori detektívok v mad'arských edíciách populárnej literatúry v prvej či druhej polovici 20. storočia? Aký bol ich kritický ohlas? 
Ako sa tieto texty čítajú dnes? A naopak: Aký je kánon mad'arských autorov kriminálnych románov preložených do slovenčiny a češtiny? Čo odzrkadluje ich výber? Rovnako môžeme postupovat aj pri mapovaní súčasnej tvorby. Uvediem romány z troch vybraných literatúr, ktoré disponujú dvomi či až tromi stredoeurópskymi prekladmi. Prvý diel historickej detektívnej série Mareka Krajewského, odohrávajúcej sa v medzivojnovom Vroclavi (Śmierć w Breslau/ Smrt' v Breslau, 1999) vyšiel v slovenčine, ${ }^{2}$ češtine i mad'arčine. Hard-boiled román Budapest noire (Budapešt' noire, 2008) od Vilmosa Kondora, časovo situovaný do rovnakého obdobia, ibaže odohrávajúci sa v mad'arskej metropole, je dostupný okrem iného aj v českom a pol'skom preklade. ${ }^{3}$ Mimoriadne populárny mysteriózny triler Jozefa Kariku Trhlina sa dočkal českého, pol'ského aj mad'arského prekladu.

2. Porovnávacia analýza kritického ohlasu populárnych diel západnej alebo východnej proveniencie. Ako príklad možno uviest' viac ako desatročný úspech severskej detektívky (švédske, nórske, dánske, islandské detektívne a kriminálne romány), ktorá sa prekladala a prekladá do všetkých štyroch jazykov a následne generuje články a kritické diskusie o jej špecifikách a možných dôvodoch úspechu na knižnom a filmovom trhu. Rovnako úspešná detektívna séria Borisa Akunina o Erastovi Fandorinovi podnietila vznik prehl'adových štúdií a kritických bilancií o jeho dielach v českej (Kouba 2014), pol'skej (Frużyńska 2011) a mad'arskej (Turi 2010) literárnej vede a publicistike. Bolo by zaujímavé porovnat ich výsledky s ciel'om načrtnút' isté súradnice stredoeurópskej recepcie tohto medzinárodne uznávaného ruského autora gruzínskeho pôvodu. Kým napríklad jeho oblúbenost' u mad'arských čitatel'ov prerástla do „erastománie“, slovenská recepcia je zatial'ovel'a rezervovanejšia.

3. Translatologicko-interpretačné sondy do prekladovej kriminálnej, hororovej, fantasy, sci-fi či špionážnej literatúry.

4. Paratextualita a vydavatel'ská prax prekladovej populárnej literatúry (stratégie prekladu titulov, adaptácia vizuálnych zložiek obalu). Prvé mad'arské preklady názvov detektívnych románov A. Christie v medzivojnovom období možno charakterizovat' ako vol'né, niekedy až svojvol'né. Zaujímavou otázkou je, či sa podobné prekladatel'ské postupy uplatňovali aj v súdobých českých či pol'ských prekladoch jej diel, prípadne aj diel iných predstavitel'ov žánru, predovšetkým západných.

Ďalší okruh javov medziliterárnej interakcie predstavuje výskum stredoeurópskeho literárneho ohlasu kanonických autorov západnej proveniencie. Spektrum možných výskumných aspektov siaha od prejavov parciálnej intertextuality (citáty, alúzie) cez komplexnejšie nadväzovania (rewriting, paródia, pastiš) až k intermediálnym transformáciám literárnych diel (filmová a hudobná adaptácia, ilustrácia, videohry). Podkladom pre porovnávanie sa môže stat' nielen autor alebo konkrétny text, ale takisto žáner, respektíve subžáner, napríklad historická detektívka (V. Kondor: Bünös Budapest/Hriešna Budapešt', 2009; Jan

2 Literárnovednou analýzou Krajewského série sa zaoberá Horváth 2021.

3 Je príznačné, že Jacek Szczerba, recenzent pol'ského vydania, začína svoj článok vetami: „Čo vyplýva z kriminálneho románu Vilmosa Kondora Budapešt' noire? Nuž to, že aj Mad'ari majú svojho Marka Krajewského“ (Szczerba 2009). 
Zábrana - Josef Škvorecký: Vražda v zastoupení, 1967), crossover (Daniela Kapitáňová: Vražda v Slopnej, 2008; Ödön Barsi: Egy lélek visszatér/Jedna duša sa vracia, 1947) či dokonca charizmatická literárna postava (Katalin Baráth: A belga/ Belgičan, 2010; Eva Beštáková: Zločin Hercula Poirona, 2016).

\section{Populárna kultúra zvonka: sociokultúrna perspektíva}

Sociálno-kultúrne zameranú reflexiu populárnej literatúry charakterizuje perspektíva širšieho, interdisciplinárneho nazerania na problematiku. Cielavedome vybrané texty slúžia v tomto prípade ako demonštračný materiál pre spoločenskovedný výskum doby, chápu sa ako citlivé indikátory istých politických, spoločenských a kultúrnych procesov a zmien danej historickej periódy. Bádatelia prípadových štúdií tohto typu analyzujú literárne texty z pozície externého pozorovatel'a, ktoré sú pre nich predovšetkým zdrojom informácií, a preto sa zameriavajú viac na ich tematickú stránku. Uprednostňujú také diela a citujú také pasáže, ktoré z pohl'adu zamerania výskumu majú náležitú výpovednú hodnotu. Úroveň jazykového a kompozičného zvládnutia zápletky a konfrontácia konkrétneho diela so žánrovým modelom sú z hladiska sledovaných ciel'ov rozboru druhoradé, poetika často ustupuje do pozadia v prospech politiky v širokom zmysle slova. Prioritou je zachytenie stôp dobovej sféry hodnôt, mentality, explicitnej či implicitnej ideologickej zaujatosti literárneho zobrazovania v pláne rozprávača či postáv, etnických a rodových stereotypov, rôznych vzorcov identity, reprezentácie spoločenských skupín, subkultúr a zvyklostí či rituálov každodenného života.

Takto zameraný výskum je spojený s nástupom kultúrnych a mediálnych štúdií, ktoré poznamenali už aj odborníkov a výskumné tímy v stredoeurópskom regióne. Možno odkázat' na dva české tituly. Populárni kultura v českém prostoru je kolektívnou monografiou, ktorá obsahuje dvadsatjeden prípadových štúdií, z hl'adiska značne komplexného výskumného predmetu podstatných tém, ako sú reprezentácia národnej a regionálnej identity, vplyv populárnej kultúry na individuálnu a kolektívnu pamät', genderové aspekty umeleckej tvorby, historické začiatky populárnej kultúry z pohl'adu spoločenských zmien a vývinu periodickej tlače, vrátane bulvárnej a fanzinov, propaganda politickej ideológie alebo špecifické znaky niektorých subkultúr (punk, skinhead, emo) a ich medializácie. Redaktori knihy sa hlásia k anglosaskej tradícii cultural studies a vyjadrujú presvedčenie, že analýza popkultúrnych diel zo spomenutých aspektov môže pomôct'v „pochopení dynamiky i statičnosti české společnosti, její (sebe)reprezentace verbalizovaných a podvědomých vzorců identifikace, které vstupují do horizontu každodenního života místních obyvatel“" (Daniel-Kavka-Machek 2013: 17). Dôležité je odkázat' takisto na stanovisko redaktorov, podla ktorých štúdium českej populárnej kultúry „by mělo být koordinováno s bádáním v dalších zemích střední a východní Evropy, jež prošly podobným socioekonomickým vývojem jako bývalé Československo“ (Daniel - Kavka - Machek 2013: 14). Rovnako vel'avravné je aj to, že autori - ako to vyplýva z poslednej kapitoly - sa inšpirovali, nie však bez kritických výhrad, aj kolektívnou monografiou Comparative Hungarian Cultural Studies, ktorá svojím tematickým záberom a prístupom rezonovala s ich vlastným projektom výskumu (Tötösy de Zepetnek - Vasvári 2011).

Ďalším príkladom je zborník Tesilová kavalérie: Popkulturníobrazynormalizace, ktorú redigovali Petr A. Bílek a Blanka Činátlová (Bílek - Činátlová 2010). 
Autori jednotlivých štúdií sa zaoberajú prejavmi ideologickej propagandy v populárnej kultúre sedemdesiatych a osemdesiatych rokov 20. storočia, ponúkajúc široké spektrum skúmaných javov od televíznych seriálov a filmových rozprávok cez populárnu hudbu, domáce umenie, športové podujatia až k pohrebným rečiam. Publikáciu možno chápat'ako pokračovanie tematicky i metodologicky vel'mi podobnej knižky James Bond a Major Zeman. Ideologizující vzorce vyprávění, ktorej zostavovatel'om bol rovnako P. A. Bílek a tiež vznikla ako výsledok (spolu)práce profesora a študentov doktorandského seminára (Bílek 2007). V tejto spojitosti sa pripomína monografia Tibora Hirscha o mýte Jamesa Bonda, obsahujúca aj kapitolu, v ktorej autor rovnako porovnáva „ideologické vzory rozprávania“ špionážnych a kriminálnych filmov východného bloku pätdesiatych až osemdesiatych rokov s Flemingovou sériou o superhrdinovi (Hirsch 1989).

Zvoleným obdobím a metodologickým prístupom, ako aj širokým chápaním populárnej kultúry sa uvedeným českým publikáciám približuje kniha pol'ských bádatel'ov Kultura popularna v Polsce w latach 1944-1989 (Populárna kultúra v Pol'sku v rokoch 1944 - 1989), ktorá ponúka pestrú paletu skúmaných žánrov, tém a javov týkajúcich sa populárnej či masovej kultúry socializmu v Pol'skej ludovej republike (populárna hudba, vojnové romány, televízne seriály, sci-fi, socialistická mládežnícka literatúra, časopisy mladých s témou erotiky a sexuálnej výchovy, milostné romány pre ženy, videohry, fungovanie propagandy a cenzúry). Autori pristupujú k produktom tohto obdobia diferencovane, nie ako k jednoliatemu celku nehodnotných výtvorov, pričom zdôrazňujú, že vedla seba figurujú diela otvorenej propagandy s ideologicky motivovanými schémami charakterov a dejových postupov aj umelecké pokusy neoficiálnej, alternatívnej poetiky (Stańczak-Wiślicz 2012).

Záujmy kultúrnych a mediálnych štúdií sú v mnohom ohl'ade spoločné, neraz sa vzájomne dopínajú a stáva sa to $\mathrm{v}$ hojnej miere práve v prípade kontextuálneho výskumu popkultúry. Vidiet' to aj v tých kolektívnych mad'arských publikáciách, ktoré sa tiež zaoberajú historicko-politickým pozadím a súčasným vnímaním populárnej kultúry obdobia socializmu. Tvorcovia zborníka Kultpontok (Kultové body) poukazujú na vznik a digitálnu cirkuláciu rôznych remedializovaných foriem súdobých televíznych a rozhlasových seriálov, komiksov, reklám a športových podujatí, pričom odkrývajú postoje a motivácie charakteristické pre ich dnešnú recepciu (nostalgia, irónia, sarkazmus, odmietnutie či zážitková participácia) a kultiváciu kolektívnej kultúrnej pamäti (Dunai-Oláh-Sebestyén 2012). Vzniklo niekol'ko prác o peripetiách populárnej hudby v časoch štátneho socializmu. Pätnást' prípadových štúdií zborníka Populáris zene és államhatalom (Populárna hudba a štátna moc) prináša dôležité materiály a analýzy nielen pre dejiny mad'arskej hudby (beat, funk, opereta, muzikál, rock, rocková opera, new wave,${ }^{4}$ estráda), ale aj pre dejiny spoločnosti a politickej moci, hlavne čo sa týka spôsobov centrálneho riadenia zábavy, vol'ného času a aktívneho formovania vkusu prostredníctvom štátom (či presnejšie vládnucou stranou) kontrolovaných masových médií ako televízia a rozhlas (Ignácz 2017). Politicky riadenú a ideologicky

4 V zdrojovej štúdii je použitý anglický výraz na jednej strane preto, aby sa odlíšili konotácie mad'arského ekvivalentu (új hullám), ako aj preto, že v tejto podobe ide o širší pojem s transmediálnou platnostou, vztahujúci sa tiež na príbuzné tendencie vo výtvarnom a filmovom umení (pozri Ignácz 2017). 
deformovanú mad'arskú zábavnú divadelnú kultúru pätdesiatych rokov 20. storočia, takzvanú socialistickú revue (divadelnú šou s propagandistickými prvkami), spracoval Dániel Molnár v monografii Vörös csillagok. A Rákosi-korszakszórakoztató ipara és a szocialista revűk (Červené hviezdy. Zábavný priemysel Rákosiho éry a socialistické revue). Obsahuje aj dôležité textové a vizuálne dokumenty (plagáty, rozhovory) tejto formy kvázi-umeleckého prejavu.

Na zachytenie jazykových osobitostí a dobovo typických znakových stratégií pol'skej aj mad'arskej „socialistickej“" populárnej literatúry a kultúry by sa dal úspešne aplikovat' kultúrno-semiotický model Vladimíra Macuru, vypracovaný na základe československých skúseností rovnakej historickej periódy (Macura 2008). Tento mediálne orientovaný a spoločensko-senzitívny prístup sa dá uplatnit aj v prípade výskumu tradičných žánrov populárnej literatúry. Mad'arský odborník na detektívnu literatúru Sándor Kálai vo svojej knihe o dejinách francúzskeho kriminálneho románu úspešne aplikoval výsledky francúzskych a frankofónnych mediálnych teórií (Pierre Bourdieu, Régis Debray, Marc Lits). Klúčové kapitoly vývinu žánru vykreslil na pozadí sociologických a paradigmatických zmien spoločnosti, ekonomiky a mediálnych technológií na prelome 19. a 20. storočia (Kálai 2012).

Súčastou sociálno-kultúrne zameraných výskumov sú aj analýzy týkajúce sa literárnej reprezentácie etnických stereotypov na osi svoje - cudzie. Každý národ si vytvára obraz tak o sebe, ako aj o iných, najmä o tých národných komunitách, ktoré sú mu zemepisne, kultúrne či jazykovo blízke. Sebaobraz národa zahŕňa v sebe imago loci (miesto, krajina, kde sa daný národ usadil), imago historiae (historická minulost', pôvod, predkovia), imago fati (historický osud národa, jeho poslanie v dejinách ludstva), imago linguae (obraz národného jazyka) a patrí sem rovnako aj takzvaný národný charakter (Rákos 2000: 173).

Etnické stereotypy sú fenoménom vedomia, čiže ide o zjednodušené vnútorné predstavy, ktoré sú kultúrne kódované a vrývajú sa do pamäti jednotlivca najmä vd'aka výchove a vzdelávaniu. Na jednej strane sú užitočné, pretože (hoci $\mathrm{v}$ zjednodušenej forme, ale predsa) reagujú na existujúce rozdiely medzi národmi a kultúrami, na druhej strane ich však treba brat' s rezervou, istým ironickým a sebaironickým odstupom, ako konštrukcie. Inak sa totiž môžu vel'mi l'ahko stat' nebezpečným prostriedkom glorifikácie svojho alebo dehonestácie iného národa.

Národné stereotypy sa oplatí osobitne skúmat' predovšetkým v epike, kde sú lepšie predpoklady pre zobrazenie povahových vlastností, historických a zemepisných reálií aj kultúrnych tradícií národov. Užší (literárno-filologický) a širší (kultúrno-historický) prístup spája v sebe imagológia ako odvetvie interkultúrne orientovanej literárnej komparatistiky. Skúmaním literárnej reprezentácie autostereotypov a heterostereotypov, mýtov, symbolov a emblémov jednotlivých národov v značnej miere prispieva k odideologizovaniu istých kolektívnych predstáv o povahe „národného charakteru“ či „národného ducha“ daného etnika (Zelenka 2018: 13).

Populárna literatúra je z tohto hl'adiska „vd'ačným“ zdrojom výskumu, pretože charakterizácia postáv sa v nej všeobecne nesie v znamení istých naratívnych a povahových stereotypov, čo sa prejavuje v ich fyziognómii, oblečení, temperamente alebo spoločenskom postavení. $V$ jej rámci sa uplatňujú aj etnické a rasové stereotypy, negatívne i pozitívne. Diela populárnej literatúry jednak 
konzervujú, jednak ironicky vyvracajú isté vžité predstavy o príslušníkoch rôznych národov a etnických skupín.

Čo sa týka stredoeurópskeho kontextu problematiky, v závislosti od počtu zainteresovaných literatúr a hl'adísk možno vyčlenit štyri základné smery výskumu: 1. porovnávací výskum toho istého obrazu v rôznych stredoeurópskych literatúrach (napríklad obraz Slováka v českej, mad'arskej a pol'skej populárnej literatúre), 2. porovnávací výskum etnických obrazov v kontexte jednej národnej literatúry (napríklad české, mad'arské a pol'ské postavy v slovenskej literatúre alebo analýza etnických sebaobrazov), 3. konfrontačné porovnávanie vzájomných obrazov dvoch literatúr (napríklad slovenské postavy v mad'arských románoch, mad'arské postavy v slovenských románoch) (Žilka 2018), 4. stredoeurópske etnické stereotypy $\mathrm{v}$ dielach západnej populárnej literatúry.

Vznik a nápadná frekvencia istých etnických stereotypov je dobovo podmienený jav. Často má ideologické korene alebo pochádza z diel starších literárnohistorických období. Vladimír Petrík poukazuje na zjednodušenú charakteristiku postáv v niektorých medzivojnových slovenských detektívkach nižšej estetickej úrovne, čo sa prejavuje aj v idealizácii svojho a zneuctení cudzieho. Negatívne postavy, konkrétne zločinci, sú často mad'arskej národnosti: „Idea, že zlí musia byt' cudzí, väčšinou Mad'ari, kým dobrí sú naši, má pôvod až hen v národnom obrodení a rozvinul ju neskôr najmä Vajanský“ (Petrík 2009: 437). V stredoeurópskych detektívkach z obdobia socializmu sa zas výber páchatel'ov riadi pevne stanovenými ideologickými a sociologickými kódmi, ktoré sa v istých prípadoch kombinujú s národnými. Zo zločinu sú pravidelne usvedčení najmä triedni či národní nepriatelia štátu: občania západných kapitalistických krajín, disidenti, kulaci, potomkovia aristokratov. Príslušníci istých národov sú preto zobrazení v negatívnom svetle, respektíve sú a priori podozriví. Nech už ide o Rakúšanov (Jareš 2019: 183), Nemcov alebo - v poviedkach populárneho súdobého mad'arského autora detektívok Bertalana Mága - zahraničných Mad'arov, vrátane občanov Československa (Bánki 2014:36).

Prirodzene, aj imagologický výskum je možné rozšírit za hranice literatúry a zahrnút do neho filmy alebo komiksy. Dobrým príkladom je štúdia Martina Škabrahu, v ktorej analyzuje film Jiř́ho Menzela Vesničko má středisková ako súčast' novodobej národnej mytológie Čechov. Jej súčastou je rezignácia na spoluvytváranie vel'kých dejín, banalizácia a ironizácia smrti a význam rodnej zeme ako symbolickej matky, ktorá svojim synom všetko odpustí (Škabraha 2013).

Intermediálne orientovaný imagologický výskum môže priniest' komplexnejší obraz auto-i heterostereotypov, ak sa sústred'uje na historickú osobu či udalost's bohatým literárno-umeleckým ohlasom aspoň v dvoch dotýkajúcich sa kultúrach stredoeurópskeho regiónu. Taký je prípad Mórica Benyovszkého/Beňovského/Beniowského, ktorého Mad'ari, Slováci i Poliaci pokladajú s rovnakou samozrejmost'ou za svojho národného hrdinu. Ibaže akýkol'vek seriózny komparatívny rozbor, ktorý sa chce vyhnút jednostrannej rétorike privlastňovania, musí brat' do úvahy očividné napätia a kontradikcie medzi literárnym sebaobrazom autora, historickými prameňmi (vrátane odlišného, nie etnicky definovaného dobového vzorca identity) a rôznymi (stredoeurópskymi) umeleckými adaptáciami jeho životného príbehu nielen vo forme historicko-dobrodružných a životopisných románov či filmov (Fried 2019), ale aj rozprávok, komiksov a divadelných 
inscenácií (tragédia, muzikál, opera, tanečná hra), a to v časovom rozpätí od konca 18. storočia až do súčasnosti.

\section{Hypertextuálny a transmediálny rozmer populárnej kultúry}

Čím viac sa približujeme $\mathrm{k}$ súčasnosti, tým viac stúpa význam internetu ako publikačnej a komunikačnej platformy populárnej kultúry. Hypertextuálne štruktúrovaná siet digitálnych textov a najrôznejších iných druhov médií ponúka nové možnosti autorského uplatnenia a zážitkovej participácie zo strany prijemcov. Sme svedkami rýchlych a dynamických interakcií užívatel'ov a ich zoskupovania do virtuálnych komunít fanúšikov, vznikajú nové, často hybridné žánre, dochádza ku kombinácii akustických a vizuálnych médií a rovnako aj k transformácii, remedializácii niektorých tradičných žánrov literatúry. Ak chceme vychádzat' z autentického spôsobu bytia a fungovania popkultúrnych literárnych artefaktov, musíme brat' ohl'ad na toto inter- a transmediálne formované prostredie tvorby a recepcie (Nagy 2018), už dávno si nevystačíme s interpretačnými metódami zameranými iba na odkrytie jazykovo-štylistických a kompozičných osobitostí textu. Napríklad pri charakteristike žánrového spektra fantasy nemožno obíst fenomén budovania autorských brandov, ktoré zabezpečujú úspešné prepájanie rôznych mediálnych platforiem - kníh, internetových románov, filmov a videohier (k tejto téme Keserü 2016).

Dôležitost' uplatnenia uvedených aspektov je zrejmá aj v prípade výskumu fandomov a fanúšikovskej literatúry, čiže fanfikcie (často sa používa iba skratka fanfic), ktorá v súčasnosti už nevychádza v printových neziskových amatérskych časopisoch (fanzine), ale v prevažnej miere sa publikuje a komentuje na internete, bud' na stránkach fanúšikovských skupín, alebo na webových megastránkach (FanFiction.net, Wattpad.com) vytvorených vyslovene na prezentáciu fanfiction. Tieto online platformy ponúkajú registrovaným používatelom publikovat' svoje diela a vol'ne komentovat' diela iných z celého sveta. Prehl'adná kategorizácia textov podla vopred daných rozsahových, tematických, žánrových, vekových a d'alších, špecifickejších kritérií poskytuje rýchlu a efektívnu orientáciu pre potenciálnych čitatel'ov v tomto rozsiahlom, permanentne sa rozrastajúcom univerze textov. Na stránkach tohto charakteru je obyčajne možnost' zvolit si aj takzvaného testujúceho čitatela (Beta Readers), ktorý svojimi postrehmi môže pomôct vylepšit gramatickú, štylistickú, logickú či naratívnu stránku už publikovaného príbehu alebo príbehu ešte iba pripravovaného na uverejnenie. Ide o špecifický typ populárnej literatúry, ktorú pišu fanúšikovia istého autora, diela či žánru v rámci fandomu, pod pseudonymom a bez nároku na zisk. Vznikajú prepisom kanonických popkultúrnych textov (pokračovanie dejovej série, doplnenie predchádzajúcich udalostí, transpozícia a mutácia príbehu či postáv), pričom zmeny sa týkajú hlavne charakteru a životného osudu protagonistov. Najlepšie to vidiet'v takzvaných crossover príbehoch, kde dochádza k stretnutiu a vzájomnej interakcii postáv diel rôznych autorov, respektíve postáv rôznych príbehov toho istého autora. Transformácie tohto typu vedú často k vzniku tematicky, žánrovo či štylisticky hybridných útvarov. Prejavom fanúšikovskej kreativity sú potom aj vizuálne popkultúrne artefakty (fanart).

V češtine a polšstine sú už dostupné monografické práce o historických a teoretických aspektoch fandomu a fanfikcie (Abbasová 2018, Kobus 2018, Pindel 
2019) a niektorí odborníci začali aj so spracovaním produkcie istých domácich fandomov (Macek 2006, Kudláč 2016, Šmídová - Filipowicz 2019). Z pohladu stre-

ن zom na historické či zemepisné reálie signalizovala svoj pôvod, svoju kultúrnu inakost'. Hoci iba sporadicky, ale predsa sa stáva, že autori siahajú po domácich klasických predlohách. Napríklad Veronika Abbasová uvádza dve české poviedky, ktoré si vypožičiavajú postavy z románu Babička Boženy Němcovej a z básne Máj Karla Hynka Máchu (Abbasová 2018: 34).

Oficiálne stránky formálnych i neformálnych zoskupení fanúšikov, individuálne a kolektívne blogy sú dôležitým zdrojom aj pre výskum laickej kritickej reflexie artefaktov populárnej kultúry. Rýchle tempo produkcie a interakcie diel rôznych, vzájomne prepojených žánrov, znakových systémov a mediálnych platforiem je možné komentovat' a interpretovat' ovel'a promptnejšie vo forme textov publikovaných na internete než na stránkach tlačených literárnych a kultúrnych časopisov, o vedeckých už ani nehovoriac. Treba zdôraznit', že „laické“ v tomto prípade nie je synonymom nekompetentnosti, pretože často práve príspevky tohto druhu upriamujú pozornost' na neprávom opomenuté diela alebo prinášajú cenné bibliografické údaje (niekedy aj precízne vypracované zoznamy titulov) niektorého segmentu popkultúrnej tvorby.

\section{Zhrnutie}

Načrtnutú fragmentárnu stredoeurópsku mozaiku existujúcich a anticipovaných výskumov populárnej literatúry treba vnímat' ako „momentku“, ktorá ukazuje produktívnu súhru odlišných, no vzájomne sa doplňujúcich orientácií a metód. Všetky tri charakterizované prístupy majú svoje oprávnenie a prinášajú dôležité údaje (hoci údaje rôzneho charakteru) pre d'alší výskum tejto oblasti. Kým nemáme prehl'ad o rozsahu produkcie populárnej literatúry, budú naše zistenia o nej, hlavne čo sa týka vývinových súvislostí, vždy iba provizórne a hodnotové súdy diskutabilné. Prirodzene, pri analýze konkrétnych diel nemôžeme odhliadnut ani od širšieho spoločenského a kultúrneho kontextu doby ich vzniku, pretože tá často zanecháva svoje stopy, viac či menej zretel'né, na rôznych rovinách textu, či už vo forme ideologických prerieknutí protagonistov, alebo v schematicky nastolených riešeniach konfliktov príbehu. A nakoniec akcentovanie recepčného, účastníckeho hl'adiska je „zdravým“ a nevyhnutným hermeneutickým korektívom, ktorý vyvažuje mylnú objektívnost' a nemennost' sugerovanú bibliografickými súpismi a rovnako aj negatívny dosah odstredivých síl kontextuálnych prístupov. Upozorňuje totiž na triviálnu okolnost', ktorú si však v dostatočnej miere nie vždy uvedomujeme, že s populárnymi románmi, poviedkami, komiksami či filmami sa konfrontujeme dnes, tu a teraz, vstupujú do nášho osobného čitatel'ského sveta, rezonujú v nás a hl'adajú si v našom recepčne poznačenom vedomí svoje miesto. Pomáha nám aj v tom, aby sme nestratili zo zretel'a, že primárnym účelom popkultúrnych artefaktov nie je reflexia spoločenských a politicko-mocenských pomerov, ale vyvolanie 
istého, tematicky a žánrovo špecifického zážitku a uspokojenie určitej estetickej potreby. Túto skutočnost' treba brat' do úvahy napríklad aj v súvislosti s inováciou výučby literatúry na všetkých stupňoch vzdelávania. Práve to je oblast', kde by sa spomenuté výsledky - hlavne účastnícky smerovaných (ale aj ostatných) - výskumov populárnej tvorby mali intenzívnejšie odrazit' a trvalejšie sa v nej integrovat. ${ }^{5}$ To je však už problematika, ktorá si žiada osobité spracovanie.

\section{Literatúra}

ABBASOVÁ, Veronika, 2018. Fanfikce. Ženská literatura nového věku. Praha: Univerzita Karlova. ISBN 978-80-730-8775-3.

ARATÓ, László, 2006. A populáris regiszter az irodalomtanításban. In SIPOS, Lajos-FÜZFA, Balázs, ed. Irodalomtanitás a harmadikévezredben. Budapest: Krónika Nova Kiadó, s. 897-904. ISBN 978-963-9423-75-6.

ARATÓ, László, 2016. Védőbeszéd a ponyvairodalom mellett. Könyv és Nevelés, roč. 20, č. 2, s. 23-34. ISSN 0454-3475.

BÁNKI, Éva, 2014. A bün nyelvét megtanulni. Tanulmányok a kemény krimiről. Budapest: Napkút Kiadó. ISBN 978-963-263-423-4.

BÁRÁNY, Tibor, 2001. Szépirodalom vs. lektür. Holmi, roč. 12, č. 2, s. 249-270. ISSN 0865-2864 .

BÉNYEI, Tamás, 2009. Kategóriaváltások: a krimi elolvashatatlansága. Alföld, roč. 60, č. 5 , s. 45-59. ISSN 0401-3174.

BÍLEK, Petr A., ed., 2007. James Bond a Major Zeman. Ideologizujicívzorce vyprávění. Př́ibram: Pistorius \& Olšanská - Paseka. ISBN 978-80-87053-06-5.

BÍLEK, Petr A. - ČINÁTLOVÁ, Blanka, ed., 2010. Tesilová kavalérie. Popkulturní obrazy normalizace. Př́bram: Pistorius \& Olšanská. ISBN 978-80-87053-44-7.

DANIEL, Ondřej-KAVKA, Tomáš - MACHEK, Jakub, 2013. Úvod. In DANIEL, Ondřej-KAVKA, Tomáš - MACHEK, Jakub, ed. Populární kultura v českém prostoru. Praha: Karolinum, s. 13-22. ISBN 978-80-246-2192-0.

DUNAI, Tamás - OLÁH, Szabolcs - SEBESTYÉN, Attila, ed., 2012. Kultpontok. Emlékezethelyek a magyar populáris kultúrában. Debrecen: Debreceni Egyetemi Kiadó. ISBN 9789633182673.

FARKAS, András, ed., 2012. Rejtö lexikon. Budapest: Quattrocento. ISBN 6155262043.

FRIED, István, 2019. Verbó elhíresedett fia földrészek és nyelvek közt. Irodalmi Szemle, roč. 62, č. 10, s. 26-46. ISSN 1336-5088.

FRUŻYŃSKA, Joanna, 2011. Intertekstualność prozy Borysa Akunina. Strategia apokryficzna (tom „Nefrytowy różaniec"). In STEMPCZYŃSKA, Barbara-MIĘSOWSKA, Lidia, ed. „Literatura środka“. Kontekst stowiański. Katowice: Wydawnictwo Uniwersytetu Śląskiego, s. 121-129. ISBN 978-83-8012-610-7.

GRÓB, László, 2012. A magyar ponyva képes bibliográfiája 1. Máriabesnyő: Attraktor. ISBN 9786155257216.

HADNAGY, Róbert - MOLNÁR, Gabriella, 2004. Agatha Christie krimikalauz. Budapest: Európa. ISBN 9630790437.

HANSÁGI, Ágnes, 2017. A komparatisztika műfaja - a tárcaregény. In SZÁVAI, Dorottya - VARGA, Zoltán Z., ed. Müfaj és komparatisztika. Budapest: Gondolat, s. 77-86. ISBN 978-963-693-835-2.

5 Pozitívne indície v tomto smere, ba v niektorých prípadoch už aj koncepčne vyzreté návrhy obsahujú publikácie mad'arských, slovenských a pol'ských bádatel'ov (Arató 2006, 2016, Jakubowski 2011, Malícková a kolektív 2015, Jakubowski 2017). 
HEGEDŰS, Orsolya, 2012. A mágia szövedéke. Bevezetés a magyar fantasy olvasásába. Dunaszerdahely: Lilium Aurum. ISBN 978-80-8062-467-5.

HIRSCH, Tibor, 1989. A James Bond mitosz. Budapest: Szabad Tér Kiadó. ISBN 963-7810-18-8. HORVÁTH, Tomáš, 2011. Tajomstvo a vražda. Model a dejiny detektívneho žánru. Bratislava: Veda. ISBN 978-80-224-1165-3.

HORVÁTH, Tomáš, 2021. Pátrania vo fantomatickom meste: Breslau retrodetektívok Mareka Krajewského. Slovenská literatúra, roč. 68, č. 3, s. 337-347. ISSN 0037-6973.

IGNÁCZ, Ádám, ed., 2017. Populáris zene és államhatalom. Budapest: Rózsavölgyi és Társa. ISBN 9786155062346.

JAKUBOWSKI, Witold, 2011. Edukacja w świecie kultury popularnej. Kraków: Impuls. ISBN 978-83-7587-346-7.

JAKUBOWSKI, Witold, ed., 2017. Pedagogika kulturypopularnej. Kraków: Impuls. ISBN 978 -83-8095-189-1.

JANÁČEK, Pavel - JAREŠ, Michal, ed., 2003. Svět rodokapsů. Praha: Karolinum. ISBN 80-246-0640-2.

JAREŠ, Michal, 2019. Dva kapitáni: Belan a Záruba. Př́ipady slovenské detektivky v edici Dobrodružné romány. Slovenská literatúra, roč. 66, č. 3, s. 180-187. ISSN 0037-6973.

KÁLAI, Sándor, 2012. Fejezetek a francia bünügyi regény történetéböl. Debrecen: Debreceni Egyetemi Kiadó. ISBN 9789633182376.

KESERÜ, József, 2016. Brandek a magyar fantasy-irodalomban. Alföld, roč. 67, č. 12, s. 91 -97. ISSN 0401-3174.

KESERÜ, József, 2021. Lehetnek sárkányaid is. A fantáziavilágok épitése mint kulturális gyakorlat. Budapest: Prae. ISBN 9786156199157.

KOBUS, Aldona, 2018. Fandom. Fanowskie modele odbioru. Toruń: Wydawnictwo Naukowe Uniwersytetu Mikołaja Kopernika. ISBN 978-83-231-4003-0.

KOUBA, Miroslav, 2014. Boris Akunin mezi postmoderním románem a populární literaturou. Př́běhy Erasta Fandorina v české literární recepci. In KUDLÁČ, Antonín-STUDENÝ, Jiří, ed. Pop \& Brak. Populární literatura v kontextu proměn literární kultury. Pardubice: Univerzita Pardubice, s. 33-48. ISBN 978-80-7395-725-4.

KUDLÁČ, Antonín K. K., 2010. Literatura přes palubu. Červený Kostelec: Pavel Mervart. ISBN 978-80-87378-25-0.

KUDLÁČ, Antonín K. K., 2014. Výzkum populární literatury v Čechách po roce 1989. Stav a perspektivy. In KUDLÁČ, Antonín-STUDENÝ, Jiří, ed. Pop \& Brak. Populární literatura v kontextu promén literární kultury. Pardubice: Univerzita Pardubice, s. 7-17. ISBN 978 -80-7395-725-4.

KUDLÁČ, Antonín K. K., 2016. Anatomie pocitu úžasu. Českápopulárnífantastika 1990-2012 v kulturním, sociálním a literárním kontextu. Brno: Host. ISBN 978-80-7491-764-6.

MACEK, Jakub, 2006. Fandom a text. Praha: Triton. ISBN 978-80-725-4856-9.

MACURA, Vladimír, 2008. Štastný věk (ajiné studie o socialistické kultư̌e). Praha: Academia. ISBN 978-80-200-1669-0.

MACHEK, Jakub, 2017. Počátky populární kulturyv českých zemích. Tištěná média a velkoměstská kultura kolem roku 1900. Př́bram: Pistorius \& Olšanská. ISBN 978-80-7579-001-9.

MALÍČEK, Juraj, 2008. Vademecum popkultúry. Nitra: Univerzita Konštantína Filozofa. ISBN 978-80-8094-287-8.

MALÍČKOVÁ, Michaela a kolektív, 2015. Praktická estetika 8: o interpretácii popkultúrneho diela. Nitra: Univerzita Konštantína Filozofa v Nitre. ISBN 978-80-558-0.

MOLNÁR, Dániel, 2019. Vörös csillagok. A Rákosi-korszak szórakoztató ipara és a szocialista revük. Budapest: Ráció Kiadó. ISBN 9786155675232.

NAGY, Péter H., 2016. Alternatívák. A popkultúra kapcsolatrendszerei. Budapest: Prae. ISBN 9786155070556.

NAGY, Péter H., 2018. A popkultúra-kutatás praxeológiája. Fórum Társadalomtudományi Szemle, roč. 20, č. 3, s. 91-101. ISSN 1335-4361.

PETRÍK, Vladimír, 2009. Z praveku slovenskej detektívky. Slovenská literatúra, roč. 56, č. 5-6, s. 435-438. ISSN 0037-6973.

PINDEL, Tomasz, 2019. Historie fandomowe. Wołowiec: Wydawnictwo Czarne. ISBN 978 -83-8049-886-0.

PLENCNER, Alexander, 2013. Teória kultúrnych úrovní. European Journal of Media, Art \& Photography, roč. 1, č. 2, s. 67-91. ISSN 1339-4940.

POTRYKUS-WOŻNIAK, Paulina, 2011. Stowniknowych gatunków i zjawisk. Warszawa: PWN Wydawnictwo Szkolne. ISBN 978-83-262-0173-8. 
RÁKOS, Péter, 2000. Nemzeti jelleg a miénk és a másoké. Pozsony: Kalligram. ISBN 80-7149-347-3.

SÁNTHA, Attila, 1996. A populáris irodalom tudománya (f)elé. Pompeji, roč. 6, č. 3-4, s. 188-203. ISSN 0865-5553.

SIVČOVÁ, Stanislava, 2017. Poznámky k slovenskému a pol'skému výskumu populárnej literatúry. Literatura i kultura popularna, roč. 23, s. 7-24. Acta Universitatis Wratislaviensis. ISSN 0867-7441.

STAŃCZAK-WIŚLICZ, Katarzyna, ed., 2012. Kultura popularna v Polsce w latach 1944 - 1989. Problemy i perspektiwy badawcze. Warszawa: Instytut Badań Literackich PAN. ISBN 978-83-61750-27-7.

ŠKABRAHA, Martin, 2013. Všichni dobří nevolníci. O symbolu země-matky ve filmu Vesničko má středisková. In DANIEL, Ondřej - KAVKA, Tomáš - MACHEK, Jakub, ed. Populární kultura v českém prostoru. Praha: Karolinum, s. 29-36. ISBN 978-80-246-2192-0.

ŠMÍDOVÁ, Tereza - FILIPOWICZ, Marcin, 2019. Česko-slovenské společenství na půdě současné fanouškovské literatury. Př́pad fandomu Harry Potter. Slovenská literatúra, roč. 66, č. 3, s. 216-232. ISSN 0037-6973.

TÖTÖSY DE ZEPETNEK, Steven - VASVÁRI, Louise O., ed., 2011. Comparative Hungarian Cultural Studies. West Lafayette: Purdue University Press. ISBN 1557535930.

TURI, Márton, 2010. Gyilkosság a tömegirodalom és a magaskultúra posztmodern menyegzőjén (Borisz Akunyin detektívregényei és a krimi-irodalom orosz hagyományai). Új Forrás, roč. 42, č. 7, s. 61-71. ISSN 0133-5332.

ZELENKA, Miloš, 2008. Středni Evropa v souvislostech literární a symbolické geografie. Nitra: Univerzita Konštantína Filozofa. ISBN 978-80-8094-371-4.

ZELENKA, Miloš, 2018. K teórii komparatistickej imagológie (Úvodné tézy). In ZELENKA, Miloš - TKÁČ-ZABÁKOVÁ, Lenka, ed. Imagológia ako výskum obrazov kultúry (K reflexii etnických stereotypov krajín V4). Nitra: Univerzita Konštantína Filozofa, s. 7-17. ISBN 978-80-558-1294-6.

ŻABSKI, Tadeusz, ed., 2006. Stownik literatury popularnej. Wrocław: Wydawnictvo Uniwersytetu Wrocławskiego. ISBN 9788370910396.

ŽILKA, Tibor, 2018. Etnicita ako prostriedok stereotypizácie (literárnych) postáv. In ZELENKA, Miloš - TKÁČ-ZABÁKOVÁ, Lenka, ed. Imagológia ako výskum obrazov kultúry (K reflexii etnických stereotypov krajín V4). Nitra: Univerzita Konštantína Filozofa, s. 17-29. ISBN 978-80-558-1294-6.

\title{
Elektronické zdroje
}

SZCZERBA, Jacek, 2009. Budapeszt noire. Gazeta Wyborcza [online]. ISSN 0860-908X. Dostupné online: https://wyborcza.pl/duzyformat/7,127290,6774652,budapeszt-noir.html

\author{
Prof. PaedDr. Kristián Benyovszky, PhD. \\ Ústav mad'arskej jazykovedy \\ a literárnej vedy \\ Fakulta stredoeurópskych štúdii \\ Univerzita Konštantína Filozofa v Nitre \\ Dražovská cesta 4 \\ 94974 Nitra \\ Slovenská republika \\ E-mail: kbenyovszky@ukf.sk
}

